\title{
鋼中アルミナ粒子のクラスタリングに及ぼす 不安定な非平衡液体酸化鉄の影響
}

\author{
溝口 利明 ${ }^{1)} \cdot$ 上島 良之 ${ }^{2 *} \cdot$ 杉山 昌章 ${ }^{2} \cdot$ 水上 和実 ${ }^{2)}$ \\ Influence of Unstable Non-equilibrium Liquid Iron Oxide on Clustering of Alumina Particles in Steel \\ Toshiaki Mizoguchi, Yoshiyuki Ueshima, Masaaki Sugiyama and Kazumi Mizukami
}

Synopsis : Alumina clusters extracted from molten steel and a cast slab at our plant were analyzed by SEM and TEM. It was found that a small amount of liquid $\mathrm{FeO}$ could accelerate the clustering of alumina inclusions in aluminum-killed steel because of the strong liquid-capillary negative pressure of liquid $\mathrm{FeO}$. The sources of the $\mathrm{FeO}$ are most likely oxygen contamination from ferroalloy additives, residual steel adhering to the refractory surfaces of ladles and vessels, and air entrainment.

Key words : Alumina; clustering; coagulation; FeO; capillary.

\section{1. 緒言}

清浄鋼の溶製は鋼材製造における最重要課題の一つであ り，2次精錬と連鋳工程の改善に注力されてきた。脱酸に 関する熱力学的知見, 介在物除去の化学工学的な知見，さ らに電磁流体力学解析手法が進歩し ${ }^{1)}$, その結果, LF P真 空処理などの2次精鍊の改善, タンディシュの高度設計, 連鋳モールドの電磁摚拌や電磁ブレーキなどの実用技術が 着実に進展している。また, 清浄性を保証するための介在 物の検出方法も進歩した ${ }^{2)}$ 。工程の最適化のために, 溶鋼 中の脱酸生成物の核生成と成長に関する基礎的知見 ${ }^{14-23)}$ はもちろん，生成した介在物の凝集合体と浮上分離に関す る数值流体モデル計算は非常に有用で，広く行われてい る ${ }^{3-13)}$ 。このような数值計算から，アルミナ粒子同士の衝 突合体係数は，粒子径が $1 \mu \mathrm{m}$ 以上のとき介在物の成長速度 に大きな影響を与える重要なファクターの一つであること が知られている。2次精鍊あるいはタンディシュにおける 実際の溶鋼中の介在物量に基づき数值計算で評価されたア ルミナ粒子の衝突合体係数は，研究者により相当異なり, 0.03〜0.7 と報告されている ${ }^{3-5,8-11,21)}$ 。これらのモデル計算 では, ブラウン運動, ファンデアワールスカ, および, 流体 力学的な引力と瓜力が考慮されており, 解析結果は貴重で ある。しかし，同じアルミナ粒子同士の衝突現象にも拘わ らず，衝突時の合体頻度が，報告によって相当な差異があ ることから，溶鋼中のアルミナ粒子のクラスタリング機構
に関する理解は未だ不十分と思われる。そこで, 著者らは 実際の取鍋溶鋼と連鋳鋳片から採取したアルミナクラス ターの形態観察を行い, アルミナクラスターの生成過程を 改めて検討した。観察の結果, 溶鋼中におけるアルミナ粒 子衝突時の合体現象に対して, 上記の力以外に, 液体酸化 物 $\mathrm{FeO}$ によるアルミナ粒子間の液体架橋力が無視できない こと, すなわち, アルミナによく濡れる液体酸化鉄が溶鋼 中に極く少量存在すると, これが溶鋼擋拌時にアルミナ粒 子に衝突した時に強力な液体架橋力を生む“バインダー” として作用して，アルミナ粒子の凝集合体を著しく促進す ることが分かった。以下に, 今回調査したアルミナクラス ターの実態を示し, その生成過程およびクラスタリングに 対する液体酸化鉄の影響について報告する。

\section{2. アルミナクラスターの観察方法}

実操業におけるアルミナクラスターを観察するために, $\mathrm{RH}$ 処理後の $270 \mathrm{t}$ 取鍋の溶鋼から採取した鋼試料と, 連鋳 鋳片の $1 / 4$ 厚部から採取した鋼試料を用意した。採取重量 は各々 $1 \mathrm{~kg}$ である。化学成分は，0.001mass\%C-0.01mass\%Si0.3 mass $\% \mathrm{Mn}-0.015 \mathrm{mass} \% \mathrm{Ti}-0.015 \mathrm{mass} \% \mathrm{Nb}-0.03 \mathrm{mass} \% \mathrm{Al}$ で ある。アルミナクラスターの観察は以下の3つの方法で 行った。すなわち，(i) 通常のスライム法 24,25$)$ で $20 \mu \mathrm{m}$ 以上 のサイズの介在物を抽出し形態をSEMで観察する方法, (ii) コールドクルーシブル再溶解 ${ }^{26)} に よ り$ 鋼試料 $90 \mathrm{~g}$ を

原著論文：ISIJ Int., Vol.53 (2013), No.4, pp.639-647

平成 25 年 5 月 13 日受付 平成 25 年 5 月27日受理 (Received on May 13, 2013; Accepted on May 27, 2013; originally published in ISIJ Int., Vol.53, 2013, No.4, pp. 639-647)

1）新日鐵住金（株）技術開発本部名古屋技術研究部（Nippon Steel \& Sumitomo Metal Corporation, Technical Research \& Development Bureau, Nagoya R\&D Lab.)

2）新日鐵住金 (株) 技術開発本部 (Nippon Steel \& Sumitomo Metal Corporation, Technical Research \& Development Bureau, 20-1 Shintomi Futtsu Chiba 293-8511)

* Corresponding author : E-mail : ueshima.br4.yoshiyuki@jp.nssmc.com

DOI : http://dx.doi.org/10.2355/tetsutohagane.99.601 
Table 1. Methods for the extraction and observation of alumina clusters for each case.

\begin{tabular}{cccccc}
\hline Case & Sampling & Alumina extraction & Observed size & Observed area & Apparatus \\
\hline I & Molten steel & Slime & $>20 \mu \mathrm{m}$ & Outer surface & SEM \\
II & Cast slab & Slime & $>20 \mu \mathrm{m}$ & Outer surface & SEM \\
III & Molten steel & Cold crucible remelting & $<20 \mu \mathrm{m}$ & Outer surface & SEM \\
IV & Cast slab & Cold crucible remelting & $<20 \mu \mathrm{m}$ & Outer surface & SEM \\
V & Molten steel & Slime & $>20 \mu \mathrm{m}$ & Cross section & TEM \\
VI & Cast slab & Slime & $>20 \mu \mathrm{m}$ & Cross section & TEM \\
\hline
\end{tabular}

$\mathrm{Ar}-2 \mathrm{vol} \% \mathrm{H}_{2}$ ガス雾囲気下で $1550{ }^{\circ} \mathrm{C} に$ 扎いて 5 分間溶解し たのち電源を切って急冷して, 主として $20 \mu \mathrm{m}$ 以下の介在 物を鋼試料表面に集積させて形態を SEMで観察する方法, (iii）スライム法で抽出したアルミナクラスターを, Gaイ オン FIB 法 ${ }^{27)}$ により切断して薄膜を作り, その内部を TEM で観察する方法の3つである。上記の鋼試料の採取方法と, 介在物の抽出と観察方法を Case I〜VIに分類して Table 1 に示した。介在物の観察には日本電子製 JSM-7001F（FESEM, 20kV) と日立製作所製HF-2000 (FE-TEM, 200kV) を， 薄膜作製には日立製作所製FB-2000A（FIB）を用いた。

\section{3. 結果}

\section{$3 \cdot 1$ スライム法で抽出したアルミナクラスターの形態}

溶鋼試料 (Case I) と連鋳鋳片試料 (Case II) から採取し たアルミナクラスターのSEM像とEDX法で測定した Al, $\mathrm{O}, \mathrm{Fe}$ の特性X線強度の線分析結果を, それぞれ Fig. 1 と 2 に示す。溶鋼から採取したアルミナクラスターは, 粒子径

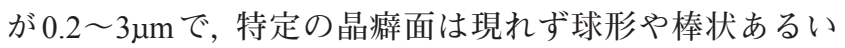
は樹枝状の種々の形状を呈するアルミナ粒子から成ってい た。また, アルミナ粒子同士は多くの箇所で, 鉄酸化物で 架橋していた (Fig.1の矢印 1 と 2 を参照)。アルミナ粒子間 が濡れて架橋しているこの形態から, この鉄酸化物は, 融 点が $1371^{\circ} \mathrm{C}^{35)}$ で溶鋼中で液体になる $\mathrm{FeO}$ と判断した。ま た, Fig.1 (a) に示したアルミナクラスター中央の $50 \times 50$ $\mu \mathrm{m}^{2}$ の視野における EDX 分析結果から，この溶鋼中のアル ミナクラスターの平均 $\mathrm{FeO}$ 濃度は $7 \mathrm{mass} \%$ であった。

鋳片中のアルミナクラスターは, 角張った形状で晶癖面 を呈するアルミナ粒子から成っており，個々の粒子径は 1 〜 $15 \mu \mathrm{m}$ で，アルミナ粒子間に鉄酸化物は全く観察されな かった (Fig.2の矢印 1 と 2 を参照)。アルミナ粒子同士は強 固に結合しており, また粒子表面には $\alpha$-アルミナの晶癖 面のテラスとレッジが多くの箇所で観察され興味深い。こ の鋳片中のアルミナクラスターの平均 $\mathrm{FeO}$ 濃度は $\mathrm{EDX} の$ 分析限界の 0.2 mass \%以下であった。

Case IとIIのそれぞれ20箇所のアルミナ粒子について EDX線分析を行った。粒子結合部における最大 Fe強度の 測定結果を Fig. 3 に示す。溶鋼中のアルミナクラスターの
$\mathrm{Fe}$ 強度最大值は鋳片から採取したものよりも明らかに大 きく，この鋳片中のクラスター結合部の $\mathrm{Fe}$ 強度最大值は, 純アルミナ平板 (ニッカトー製 SSA-S, 99.6mass \% $\mathrm{Al}_{2} \mathrm{O}_{3}$ $0.1 \mathrm{mass} \% \mathrm{SiO}_{2}$ ) と同程度のバックグラウンドレベルであっ た。溶鋼と鋳片のアルミナ粒子結合部の $\mathrm{FeO}$ 濃度には明確 な差があることが分った。

\section{$3 \cdot 2$ コールドクルーシブル再溶解法で抽出したアルミナクラ スターの形態}

コールドクルーシブル再溶解法により, 溶鋼試料 (Case III) と連鋳鋳片試料 (Case IV) から抽出したアルミナクラ スターをSEMで観察した。その結果を Fig.4に示す。溶鋼 から抽出したアルミナクラスターは, 粒子径 $0.1 〜 3 \mu \mathrm{m}$ の 晶癖面を示さない種々の形状のアルミナ粒子から成り，己 れらが微量の $\mathrm{FeO}$ で架橋して結合した形態が多数観察され た (Case III)。短時間のコールドクルーシブル再溶解のあ と直ちに急冷してアルミナクラスターを鋼試料表面に固定 したので, このようなわずかな量の $\mathrm{FeO} の$ 架橋まで明瞭に 観察できた。鋼試料表面の影響を避けるために，十分アル ミナクラスターで鋼試料表面が被覆された部分を選んで $\mathrm{EDX}$ 分析を行った結果, アルミナクラスター中の平均 $\mathrm{FeO}$ 濃度は4〜 mass\%であった。

鋳片から抽出したアルミナクラスターは, 個々の粒子 径 $1 \sim 15 \mu \mathrm{m}$ のアルミナ粒子同士が強固に焼結した形態で あり，結合部に $\mathrm{FeO}$ は検出されなかった (Case IV)。また, 多くの部位でアルミナ晶癖面のテラスやレッジが観察さ れた。クラスター中の平均 $\mathrm{FeO}$ 濃度は, $\mathrm{EDX} の$ 分析限界の $0.2 \mathrm{mass} \%$ 以下であった。本結果は, 前述のスライム法で抽 出したクラスター介在物の観察結果とほほ一致している。

\section{$3 \cdot 3$ アルミナクラスターの内部構造}

溶鋼試料 (Case V) と連鋳鋳片試料 (Case VI) からスラ イム法で抽出したアルミナクラスター断面のTEM像を Fig.5 に示す。FIB切断箇所をSEM写真のA-A'とB-B'で示 す。ここで，溶鋼からスライム抽出したクラスターの多く は結合部が細くて非常に脆くFIB切断中に壊れるので，切 断に耐える太い結合部を持つクラスターを選び観察試料 とした。TEM観察の結果, このようなアルミナクラスター

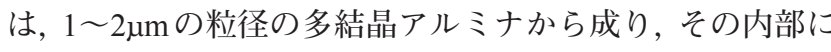
直径 10〜 500nmの微細な金属鉄粒子が分散しており, 特に 


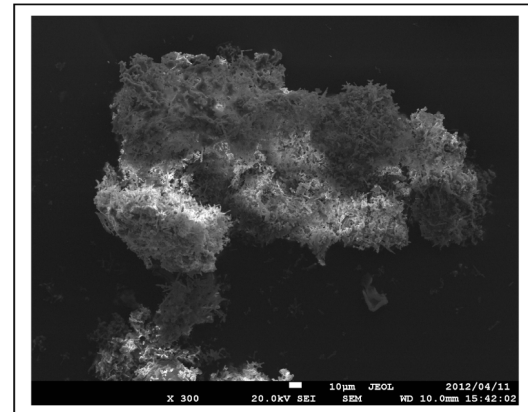

(a)

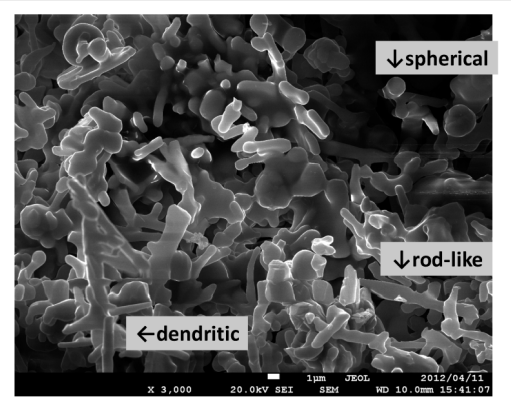

(b)

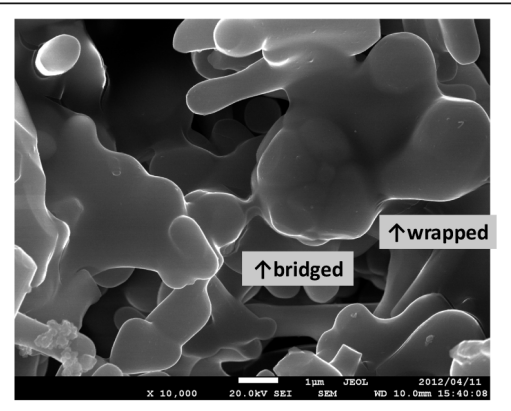

(c)

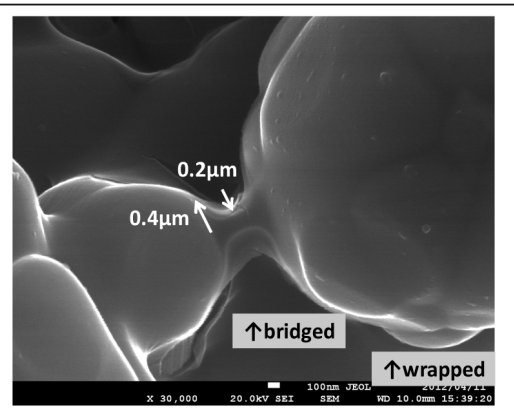

(d)

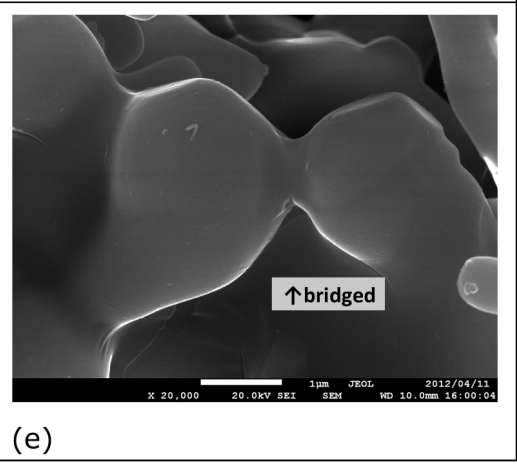

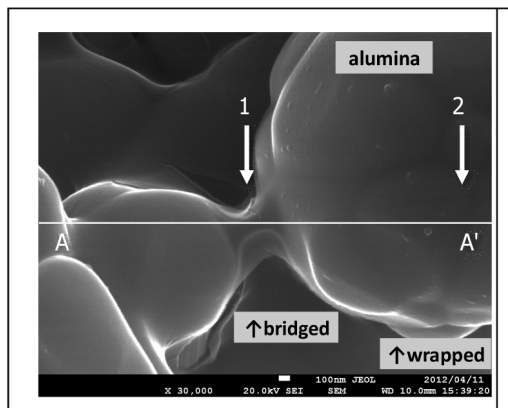

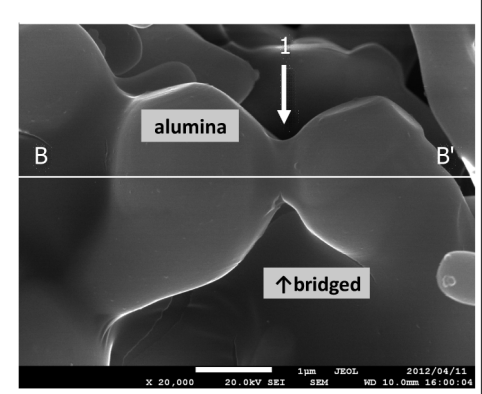

(e1)
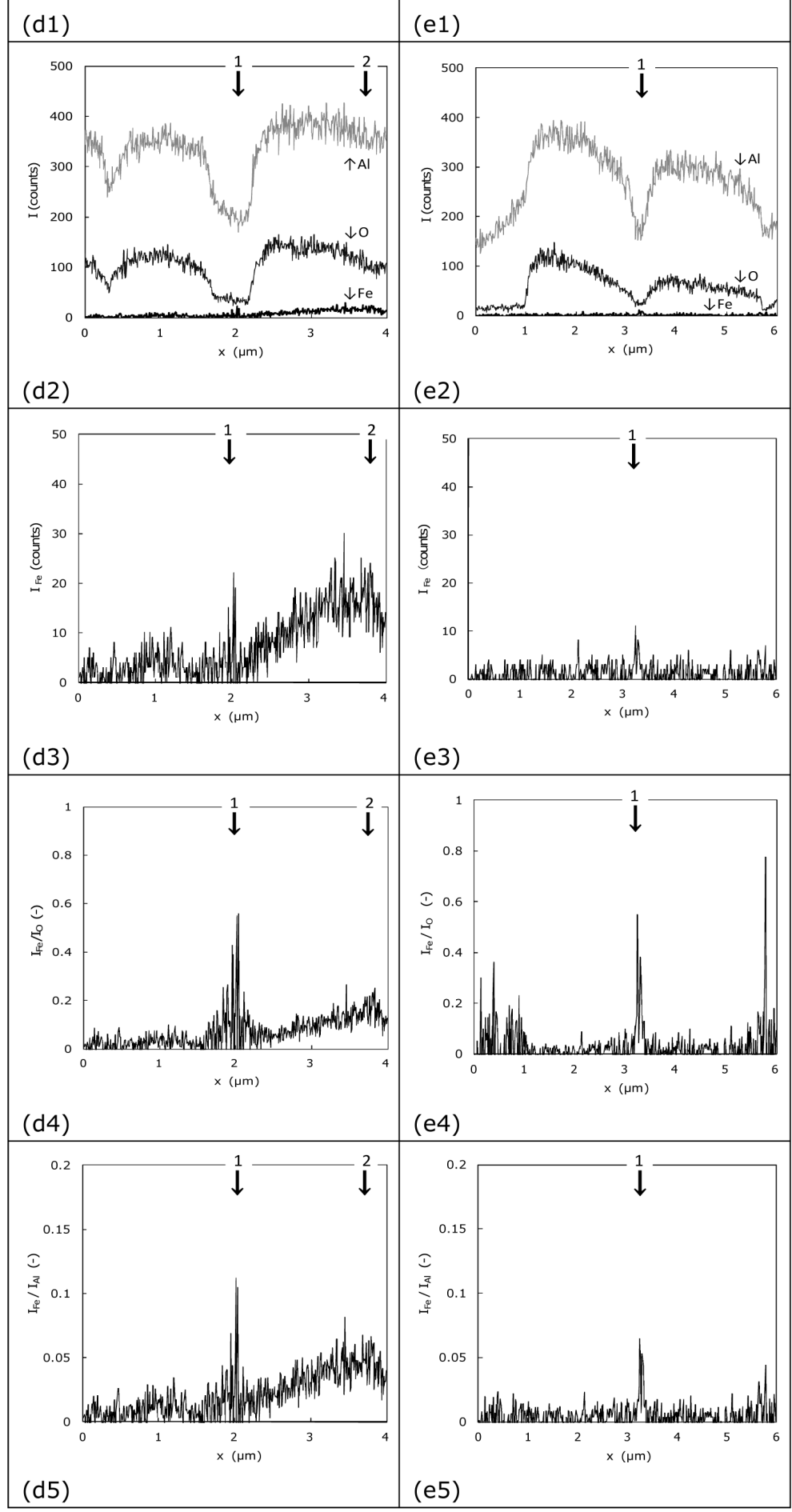

Fig. 1. SEM images and line analyses of alumina clusters extracted from molten steel using a slime method (Case I); images (b)-(e) are enlargements of the center part of (a); graphs (d2)-(d5) and (e2)-(e5) are profiles of X-ray intensity, I, taken at lines A-A' in (d1) and line B-B' in (e1), respectively; X represents the distance from A toward A' or from B toward B'; Fe peaks were distinctly found between the alumina particles (See arrows $\downarrow$ in (d2)-(d5) and (e2)-(e5)). 


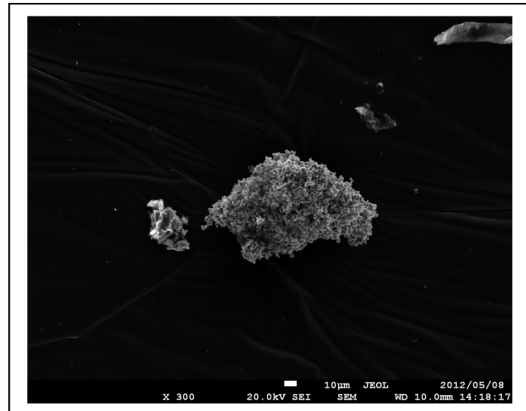

(a)

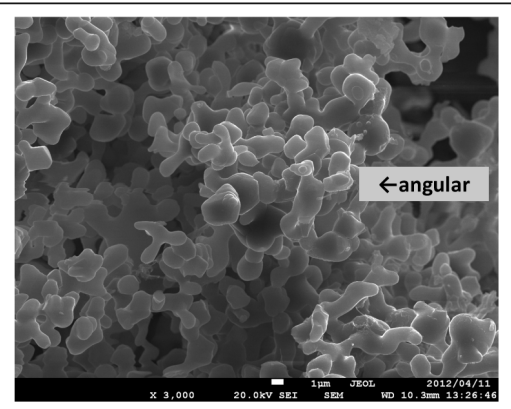

(b)

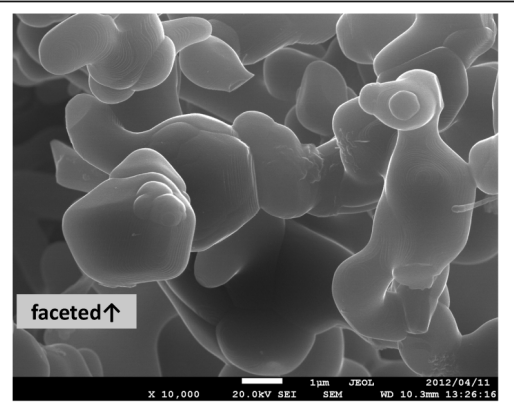

(c)

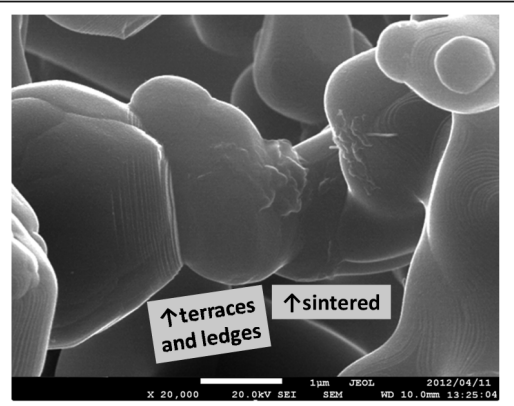

(d)

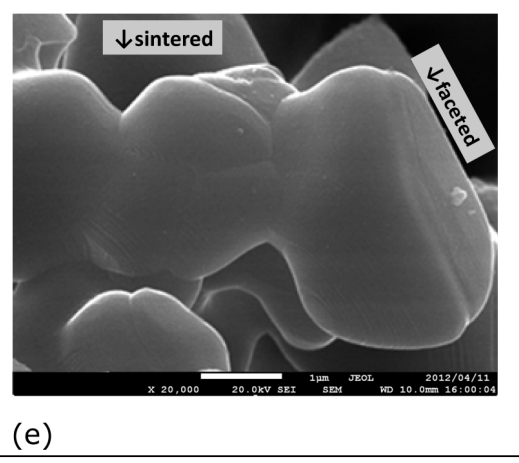

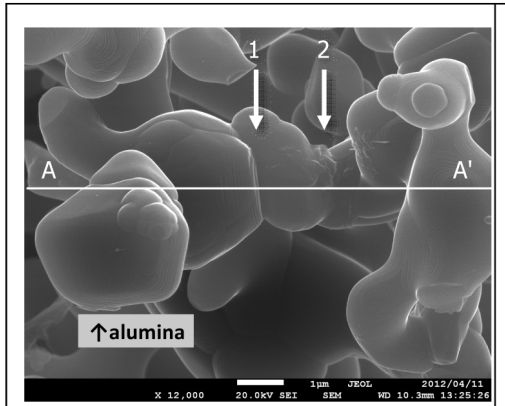

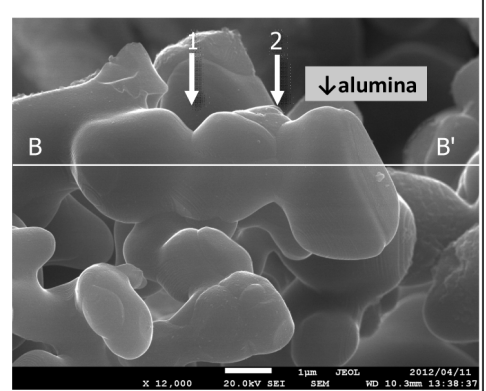

(d1)

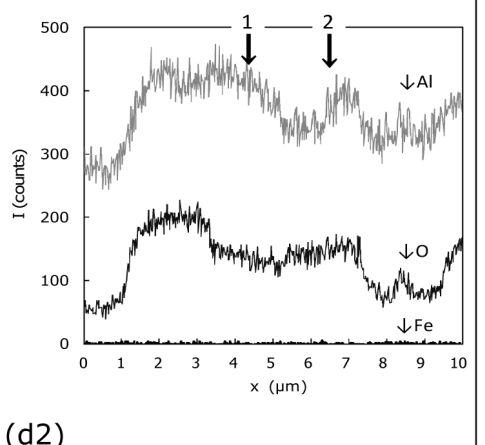

(e1)

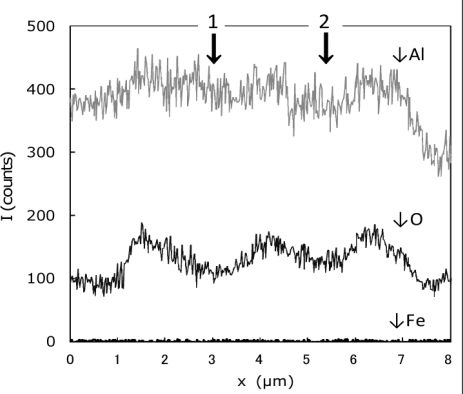

(e2)
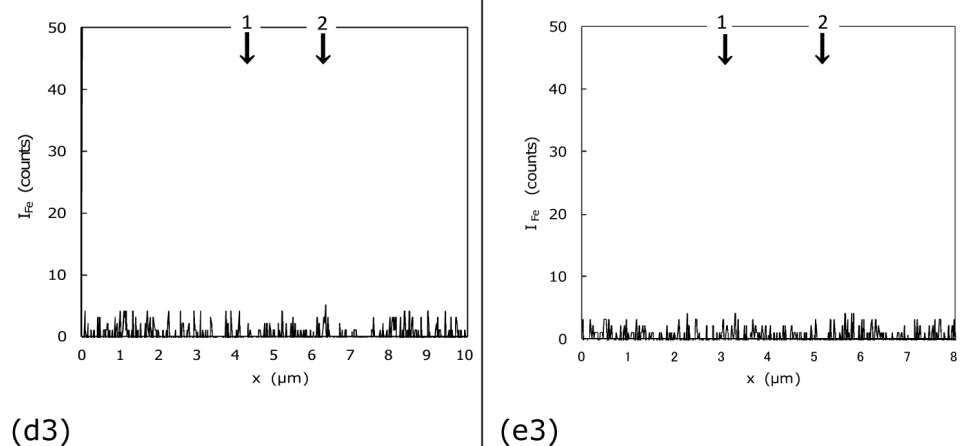

(e3)
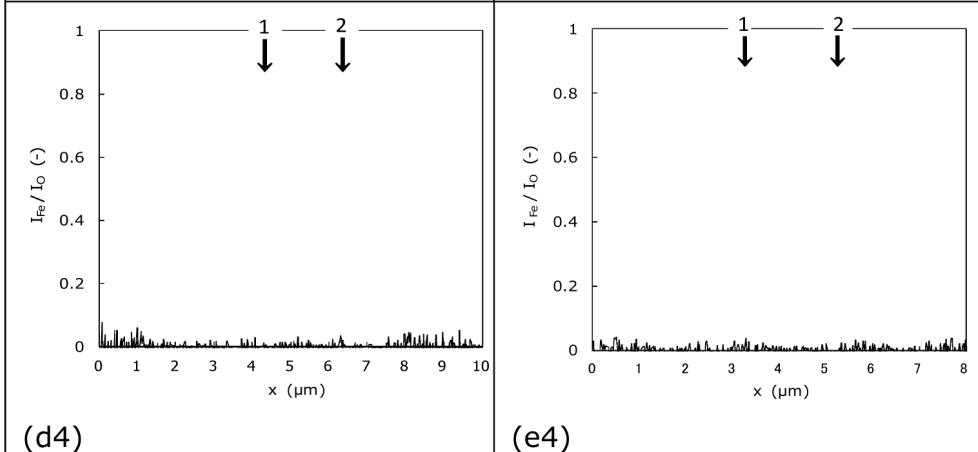

(e4)

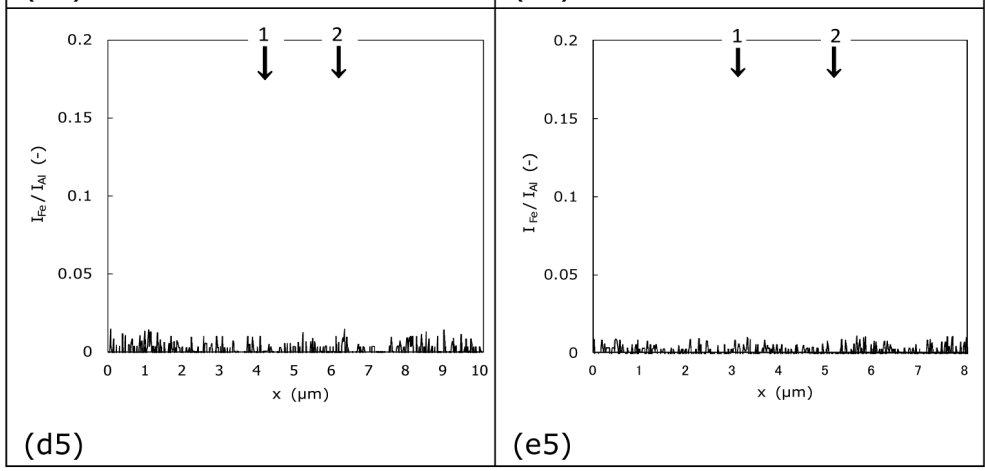

(d5)

(e5)

Fig. 2. SEM images and line analyses of alumina clusters extracted from a cast slab using a slime method (Case II); images (b)-(e) are enlargements of the center part of (a); graphs (d2)-(d5) and (e2)-(e5) are profiles of X-ray intensity, I, taken at lines A-A' in (d1) and line B-B' in (e1), respectively; X represents the distance from A toward A' or from B toward B'; no Fe peaks were found between the alumina particles (See arrows $\downarrow$ in (d2)-(d5) and (e2)-(e5)). 
アルミナ結晶粒界に多数存在することが分った (Case V)。 前述のアルミナクラスター外観のSEM観察結果と合わせ て,この金属鉄粒子はアルミナ粒子に付着した $\mathrm{FeO}$ が, ク ラスター周囲の鋼中溶存 $\mathrm{Al} に よ り$ 還元されてできたもの と推定している。

一方, 鋳片から抽出したアルミナクラスターは, 結晶粒 径が 5 10umに鋳造中に成長した多結晶アルミナから成 り，金属鉄粒子は全く検出されなかった (Case VI)。3・1 章と $3 \cdot 2$ 章で述べた観察結果と合わせて, 溶鋼中および鋳 片中のアルミナクラスターの特徵を Table 2 によとめた。

\section{4. 考察}

\section{$4 \cdot 1$ アルミナクラスターの形成}

$\mathrm{A} 1$ 脱酸溶鋼に打けるアルミナクラスターの形成機構を 考察する。前述の溶鋼打よび鋳片から採取したアルミナク ラスターの観察結果から推定したアルミナクラスターの生 成機構を Fig.6に示す。アルミナクラスターは以下の4段階 を経て生じる。

(i) $\mathrm{Al}$ 脱酸溶鋼において, $1550^{\circ} \mathrm{C}$ で $0.2 \mathrm{mass} \%$ 以上の酸素污 染が局所的に発生すると, Fe-O状態図 ${ }^{35)}$ から，(1) 式と (2) 式に示すとおり固体アルミナと液体 $\mathrm{FeO}$ の両方が生成する。

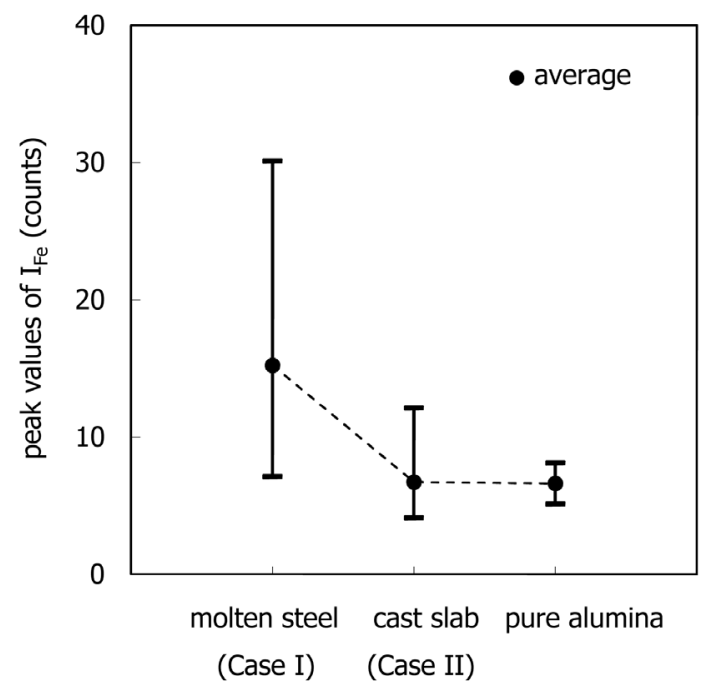

Fig. 3. Peak values of $\mathrm{I}_{\mathrm{Fe}}$ observed by X-ray line analyses for alumina clusters extracted from the molten steel (Case I) and the cast slab (Case II); the number of measurements was 20 in each case; the pure alumina sample was a flat plate with a composition of $99.6 \mathrm{mass} \% \mathrm{Al}_{2} \mathrm{O}_{3}$ $0.1 \mathrm{mass} \% \mathrm{SiO}_{2}$.

$$
\begin{aligned}
& \mathrm{Fe}+\underline{\mathrm{O}}=\mathrm{FeO} . . . . . . . \\
& 2 \underline{\mathrm{Al}}+3 \underline{\mathrm{O}}=\mathrm{Al}_{2} \mathrm{O}_{3} .
\end{aligned}
$$

（ii）溶鋼擋找により $\mathrm{FeO}$ 粒子がアルミナ粒子と衝突したと き, 濡れ性が良いため $\mathrm{FeO}$ 粒子はアルミナ粒子に容易に付 着する。この液体 $\mathrm{FeO}$ 粒子は一種の “バインダー”として作 用し，アルミナ粒子の凝集合体を促進する。

(iii) この $\mathrm{FeO}$ は $\mathrm{Al}$ 脱酸溶鋼では熱力学的に不安定である

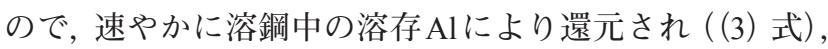
生成した微細な金属鉄粒子がアルミナクラスター内部に残 留する。

$$
3 \mathrm{FeO}+2 \underline{\mathrm{Al}}=3 \mathrm{Fe}+\mathrm{Al}_{2} \mathrm{O}_{3}
$$

（iv）この微細な金属鉄粒子は，鋳造中にアルミナクラス ター内部から外へ粒界拡散により排出され，鋳片中のアル ミナクラスターには，もはやこの金属鉄粒子は存在しない。

\section{$4 \cdot 2$ 液体酸化物が付着したアルミナ粒子間の引力}

一般に，静止媒体中に置かれた粒子間には3つの力，即 ち, ファンデアワールスカ, クーロン力, および, 液体架橋 力が働く ${ }^{29)}$ 。溶鋼中に浮遊するアルミナ粒子は電気的に中 性でクーロン力はゼロであるので，ファンデアワールスカ と液体架橋力を考察する。単純化のために, Fig.7に示した とおり, 球形で同一半径の隣接する 2 個のアルミナ粒子を 考える。

(i) ファンデアワールスカ

溶媒の溶鋼 (物質2) の中に置かれた同一半径rの2個の アルミナ粒子間 (物質 1) のファンデアワールスカ $\mathrm{F}_{\mathrm{v}}$ と換 算圧力 $\mathrm{P}_{\mathrm{v}}$ は，(4) 式と（5）式で表される29)。

$$
\begin{aligned}
& \mathrm{F}_{\mathrm{v}}=\mathrm{A}_{121} /\left(12 \mathrm{z}^{2}\right) \cdot \mathrm{r} \ldots \ldots \ldots \ldots \ldots \ldots \ldots \ldots \ldots \ldots \ldots \ldots \\
& \mathrm{P}_{\mathrm{v}}=\mathrm{F}_{\mathrm{v}} /\left(4 \pi \mathrm{r}^{2}\right)=\mathrm{A}_{121} /\left(48 \pi \mathrm{rz}^{2}\right)
\end{aligned}
$$

ここで， $\mathrm{A}_{121}$ は溶鋼中におけるアルミナ粒子間のハー マーカー係数で, $\mathrm{z}$ は原子スケールの表面凹凹を含めた粒 子間隔である ${ }^{30)}$ 。さら， $A_{121}$ は，(6) 式で示される ${ }^{31) 。 ~}$

$$
A_{121}=\left(\sqrt{A_{11}}-\sqrt{A_{22}}\right)^{2}
$$

$\mathrm{A}_{11}$ と $\mathrm{A}_{22}$ は真空中におけるアルミナと鉄のハーマー カー係数で，それぞれの報告值 $\mathrm{A}_{11}=15.5 \times 10^{-20} \mathrm{~J}$ と $\mathrm{A}_{22}=$ $21.2 \times 10^{-20} \mathrm{~J}^{32)}$ を(6) 式に代入すると, $\mathrm{A}_{121}=0.45 \times 10^{-20} \mathrm{~J}$ となる。粒子間距離として, $\mathrm{z}=1 \sim 10 \mathrm{~nm}$ と仮定した。これ は， $\alpha$-アルミナの (0001) 底面間隔の 1～10層分の表面凹

Table 2. Characteristics of the alumina clusters before and after casting.

\begin{tabular}{cccccc}
\hline Sampling & $\begin{array}{c}\text { Individual alumina } \\
\text { particle size }(\mu \mathrm{m})\end{array}$ & Surface morphology & $\begin{array}{c}\text { Neck diameter } \\
(\mu \mathrm{m})\end{array}$ & Neck materials & Case \\
\hline Molten steel & $0.1-4$ & Non-faceted & $0.1-3$ & $\mathrm{FeO}, \mathrm{Fe}^{*}, \mathrm{Al}_{2} \mathrm{O}_{3}$ & $\mathrm{I}, \mathrm{III}, \mathrm{V}$ \\
Cast slab & $1-15$ & Faceted & $1-8$ & $\mathrm{Al}_{2} \mathrm{O}_{3}$ & II, IV, VI \\
\hline
\end{tabular}

* Metallic Fe particles were most likely created by reduction of $\mathrm{FeO}$ with dissolved $\mathrm{Al}$ in steel. 


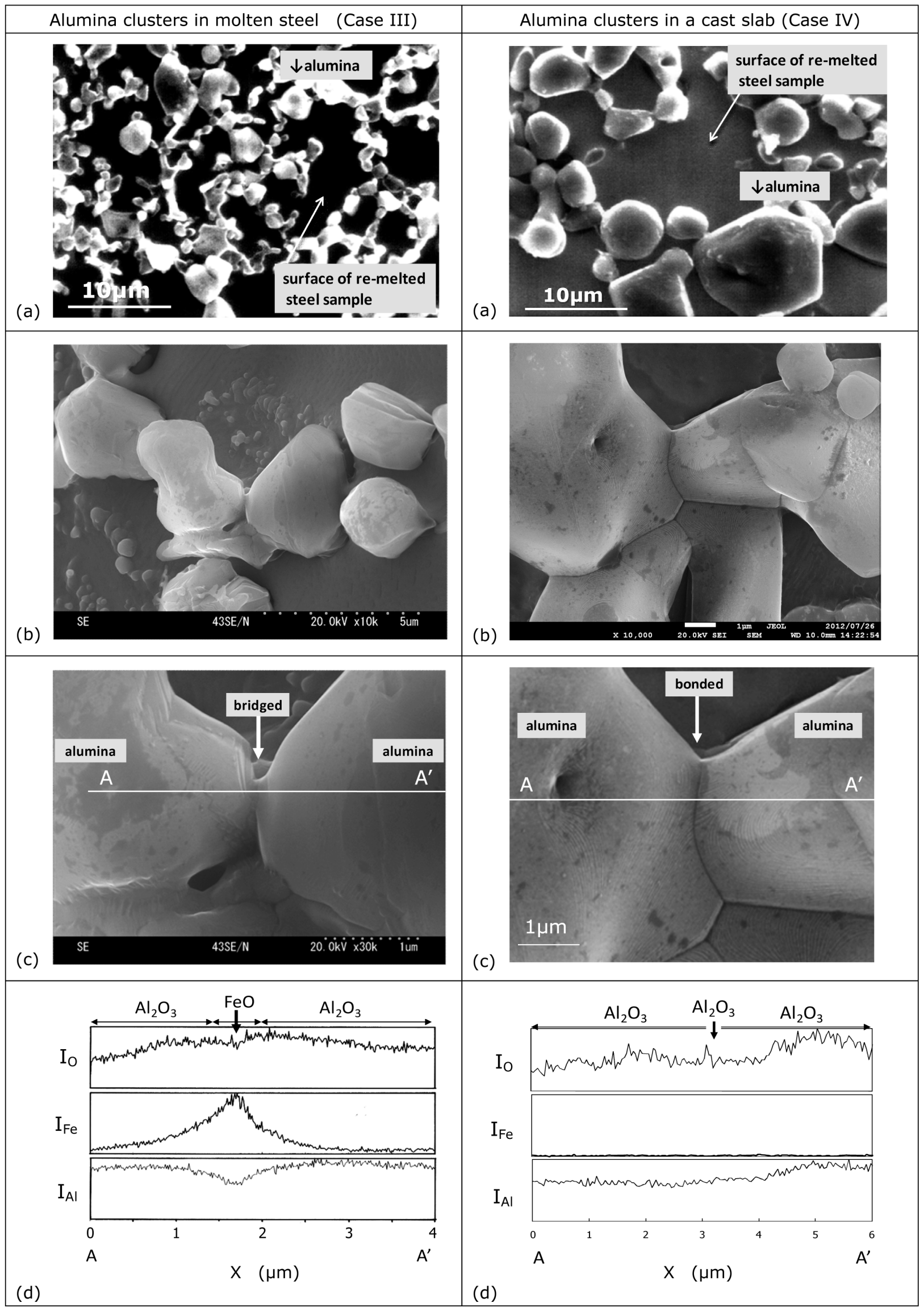

Fig. 4. SEM images and line analyses of the alumina clusters extracted from molten steel and a cast slab through the use of a cold crucible remelting method; images (b) and (c) are enlargements of (a); graphs (d) are X-ray intensity profiles taken at line A-A' in (c); $\mathrm{X}$ represents the distance from A toward A'; Fe peaks were found between the alumina particles in the molten steel (Case III), whereas no peaks were found in the cast slab (Case IV); see arrows $\downarrow$ in (d). 


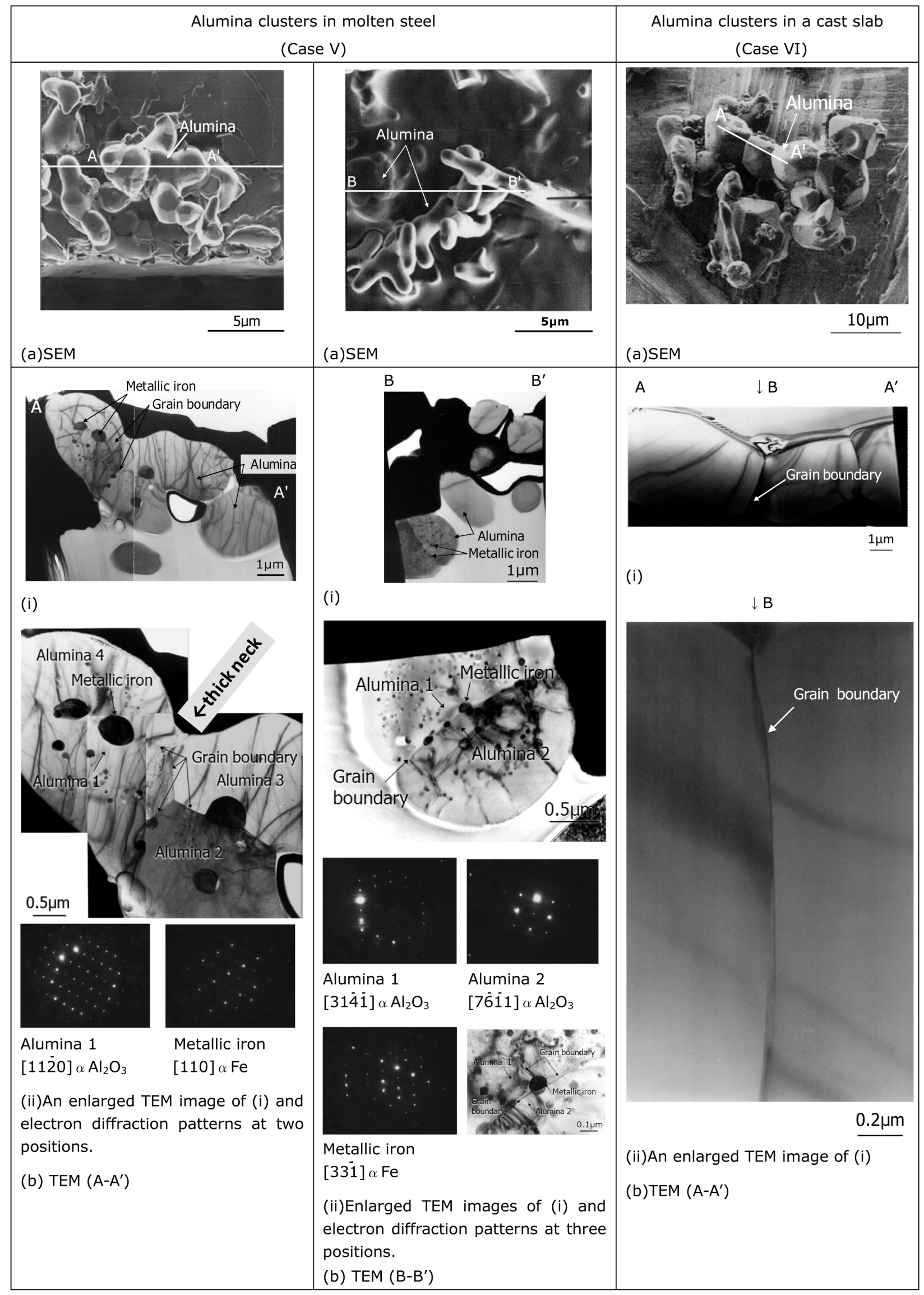

Fig. 5. SEM images of the surface of alumina clusters and TEM images of their cross sections taken along lines A-A' and B-B' in (a); images (ii) are enlargements of (i) shown in (b); many metallic iron particles were found at the alumina grain boundaries and also on the inside of the grains in the molten steel (Case V); on the other hand, no such metallic iron particles were found in the alumina clusters in the cast slab (Case VI). 


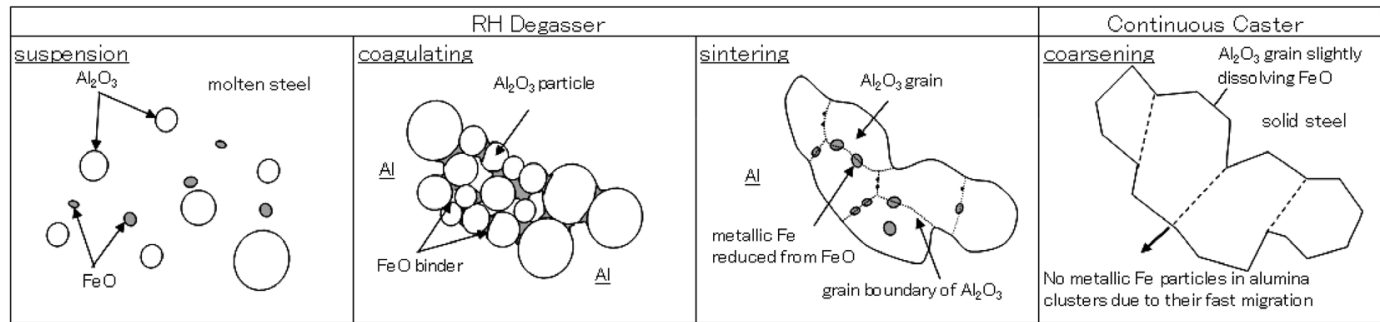

Steps

Chemical reactions and related phenomena

(i) Suspension

If high oxygen contamination $>0.2 \% \mathrm{O}$ or $\mathrm{Po}_{2}>10^{-9} \mathrm{~atm}^{35)}$ occurs,

$\mathrm{Fe}+\mathrm{O}=\mathrm{FeO}(\mathrm{I})$

(1)

$2 \underline{\mathrm{Al}}+3 \underline{\mathrm{O}}=\mathrm{Al}_{2} \mathrm{O}_{3}(\mathrm{~s})$

(2)

(ii) Coagulating FeO works as a "binder" at the moment of collision.

(iii) Sintering

FeO is gradually reduced by $\mathrm{Al}$ in steel.

$3 \mathrm{FeO}(\mathrm{I})+2 \mathrm{Al}=3 \mathrm{Fe}+\mathrm{Al}_{2} \mathrm{O}_{3}(\mathrm{~s}) \quad \ldots(3)$

(iv) Coarsening Metallic Fe particles migrate to steel, and faceted planes develop on alumina surfaces to minimize interfacial energy.

Fig. 6. Schematic drawings and an explanation of the formation of the alumina clusters; they arise through four steps: (i) suspension, (ii) coagulating, (iii) sintering, and (iv) coarsening; the step (ii) was observed in Case I and III, the step (iii) was observed in Case V, and the step (iv) was observed in Case II, IV, and VI, respectively.
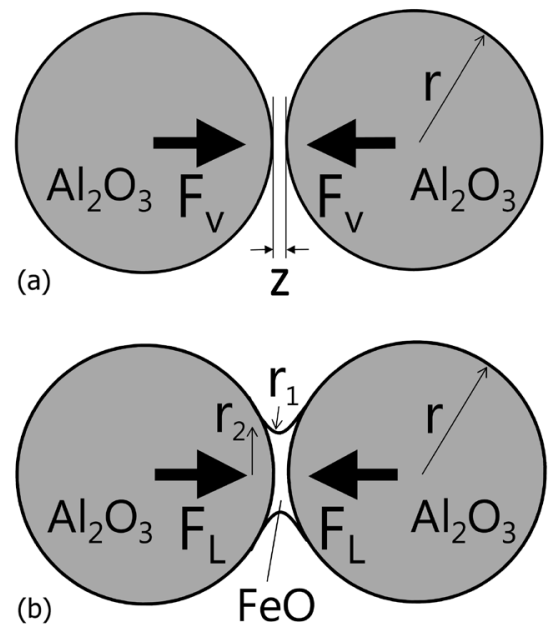

Fig. 7. Schematic drawings of alumina particle attraction in molten steel by (a) van der Waals force $\mathrm{F}_{\mathrm{V}}$ and (b) liquidcapillary force $F_{L}$.

凸に相当するものである。これらの条件のもとで，ファン デアワールスカと換算圧力は，それぞれ $\mathrm{F}_{\mathrm{v}}=1 \times 10^{-12} \sim 1$ $\times 10^{-9} \mathrm{~N}$ および $\mathrm{P}_{\mathrm{v}}=1 \times 10^{-7} \sim 1 \times 10^{-4} \mathrm{~atm}$ となる（Fig.8 中 の細い実線)。また，溶鋼中のアルミナ粒子の浮力も困中に 合わせて示す (Fig.8 中の破線)。両者を比較して，溶鋼中の アルミナ粒子間のファンデアワールスカは, せいぜい, 半 径 $\mathrm{r}=10 \mu \mathrm{m}$ のアルミナ粒子の浮力と同程度であることが 分った。

(ii) 液体架橋力

アルミナ粒子間の $\mathrm{FeO}$ の濡れにより発生する液体架橋力 $\mathrm{F}_{\mathrm{L}}$ と換算圧力 $\mathrm{P}_{\mathrm{L}}$ は，(7) 式と（8）式のヤングーラプラスの 式で表される29)。

$$
\begin{aligned}
& \mathrm{F}_{\mathrm{L}}=\pi \mathrm{r}_{2}{ }^{2} \cdot \sigma \cdot\left(1 / \mathrm{r}_{1}-1 / \mathrm{r}_{2}\right)+2 \pi \mathrm{r}_{2} \cdot \sigma \\
& \mathrm{P}_{\mathrm{L}}=\sigma \cdot\left(1 / \mathrm{r}_{1}-1 / \mathrm{r}_{2}\right) \ldots \ldots \ldots \ldots \ldots \ldots \ldots \ldots \ldots \ldots \ldots \ldots \ldots \ldots \ldots \ldots
\end{aligned}
$$

$\sigma$ は $\mathrm{FeO}$ と溶鉄間の表面張力 $\left(250 \mathrm{mN} / \mathrm{m}^{28)}\right), \mathrm{r}_{1}$ と $\mathrm{r}_{2}$ は $\mathrm{FeO}$ の直交する2つの主曲率半径で $\mathrm{r}_{1}$ はいわゆる “負の ネック半径”であり，ここでは引力を正の值で示した。

Fig.1のCase I と Fig.4のCase III に示したSEM観察結果 に基づき, $\mathrm{r}_{1}=0.1 \sim 0.5 \mu \mathrm{m}$, 且つ, $\mathrm{r}_{2}=\mathrm{r} / 2$ とすると, 溶鋼か ら抽出したアルミナクラスターで観察した個々の構成ア ルミナ粒子半径 $\mathrm{r}=1 \sim 10 \mu \mathrm{m}$ において, 液体架橋力と換算 圧力は，それぞれ $\mathrm{F}_{\mathrm{L}}=1 \times 10^{-6} \sim 1 \times 10^{-3} \mathrm{~N}$ および $\mathrm{P}_{\mathrm{L}}=2 \sim$ 20atmとなる (Fig.8中の太い実線)。従って, もし, 少量の $\mathrm{FeO}$ で濡れたアルミナ粒子が溶鋼中で衝突すると $\mathrm{FeO}$ の液 体架橋力により直ちに2 20atmの負圧が発生して, 粒子同 士が強力に付着することになる。この值は, 前述のファン デアワールスカはもちろん, 通常の操業状態における溶鋼 静圧や動圧よりも大きい。従って, $\mathrm{A} 1$ 脱酸溶鋼におけるア

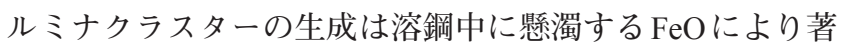
しく促進され, $\mathrm{FeO}$ 量がクラスター化の度合を決めてい るものと考えられる。

溶鋼中の液体介在物による固体介在物の凝集合体促進に ついては，すでに種々の場合で報告されている。例えば, $\mathrm{Si}$ 脱酸鋼の場合, 液体マンガンシリケートによる固体シリ 力介在物の凝集合体の促進 $5,12,14,17,18), \mathrm{Al}$ 脱酸鋼の場合, 実 操業の解析から液体スラグの巻き込みによる固体アルミナ 介在物の凝集合体の促進 ${ }^{33)}$, 液体 $\mathrm{FeO}$ による連鋳ノズル付 着増加のラボ検討 ${ }^{34)}$ が知られている。今回の観察結果は, 液体介在物による固体介在物の凝集合体促進という点はこ 

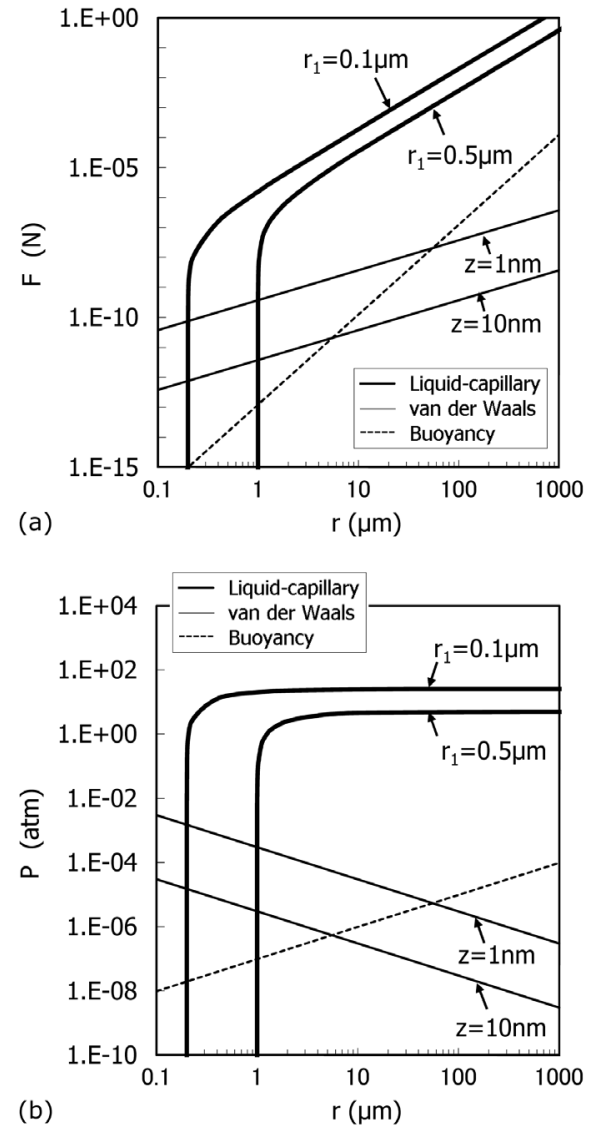

Fig. 8. Attractive forces between alumina particles in molten steel and their buoyancy forces; the calculated forces and the corresponding pressures are shown in (a) and (b), respectively.

れまでの報告と一致しているが, $\mathrm{A} 1$ 脱酸溶鋼の中では, 当 然, 液体 $\mathrm{FeO}$ は熱力学的に不安定であり, 固体アルミナ介 在物の凝集合体促進作用は限られた短い時間だけ現れる点 が重要である。この $\mathrm{FeO}$ の発生源として, 合金原料中の残 留酸素, 取鍋や真空槽の耐火物表面に付着した地金の酸化 物, および, 空気の巻込が考えられる。従って, 鋼の清浄性 と製品品質を保証する上で, このような酸素污染は最大限 防ぐ必要がある。

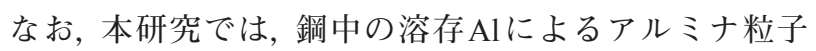
間の架橋 $\mathrm{FeO}$ の還元速度と, アルミナクラスター内部から 溶鋼への金属鉄粒子の排出速度について, 定量的な考察 を行わなかった。また, 中間化合物の $\mathrm{FeOAl}_{2} \mathrm{O}_{3}$ は, 融点が $1780^{\circ} \mathrm{C}$ と高く ${ }^{36)}$, 溶鋼中ではアルミナ粒子間で液体架橋力 を発生する酸化物ではないので触れなかったが，アルミナ 粒子の凝集合体後の焼結段階で過渡的に生成していた可能 性がある。これらの点について速度論的な観点で理解を深 めるためには，更なる検討が必要である。

\section{5. 結論}

実操業における $\mathrm{A} 1$ 脱酸溶鋼とその連鋳鋳片から採取し た介在物の観察結果に基づき，溶鋼中のアルミナクラス
ターの生成機構を検討した。その結果, $\mathrm{A} 1$ 脱酸溶鋼中に懸 濁する少量の液体 $\mathrm{FeO}$ が 2 20atmの強い液体架橋力を発 生させ，アルミナ粒子のクラスタリングを促進することが 明らかになった。この $\mathrm{FeO} の$ 発生源として, 合金原料中の 残留酸素, 取鍋や真空槽の耐火物表面に付着した地金の酸 化物, および, 空気の巻込が考えられる。従って, 鋼の清浄 性と製品品質を保証する上で, このような酸素污染は最大 限防ぐ必要がある。

\section{文献}

1 ) Advanced Physical Chemistry for Process Metallurgy, ed. by N.Sano, W.-K.Lu, P.Riboud and M.Maeda, Academic Press, London, (1997).

2 ) L.Zhang and B.G.Thomas: ISIJ Int., 43(2003), 271.

3 ) K.Nakanishi and J.Szekely: Trans. Iron Steel Inst. Jpn., 15(1975), 522.

4 ) K.Shirabe and J.Szekely: Trans. Iron Steel Inst. Jpn., 23(1983), 465.

5 ) Y.Miki, H.Kitaoka, T.Sakuraya and T.Fujii: Tetsu-to-Hagané, 78(1992), 431

6 ) I.Sawada, K.Okazawa, E.Takeuchi, K.Shigematsu and H.Tanaka: Nippon Steel Tech. Rep., 67(1995), 7.

7 ) K.Umetsu, K.Fujisaki, K.Wajima, S.Nishi, K.Sawada and T.Ueyama: Nippon Steel Tech. Rep., 67(1995), 13.

8 ) W.Yamada, T.Matsumiya, S.Fukumoto, M.Wajima and H.Tanaka: Nippon Steel Tech. Rep., 67(1995), 21.

9 ) Y.Miki, Y.Shimada, B.G.Thomas and A.Denissov: Iron Steelmaker, (1997), 31.

10) K.Fuchigami, M.Wakoh, N.Imamura, K.Endoh, A.Kiyose and I.Sawada: Tetsu-to-Hagané, 85(1999), 368.

11) L.Zhang, S.Taniguchi and K.Cai: Metall. Trans. B, 31B(2000), 253.

12) K.Lei, D.-Q.Geng and J.-C.He: ISIJ Int., 49(2009), 1575.

13) K.Yamamura, S.Matsuzaki, T.Toh, W.Yamada and J.Nakagawa: Shinnittetsu Giho (Nippon Steel Tech. Rep. in Japanese), 391(2011), 143.

14) N.Sano, S.Shiomi and Y.Matsushita: Tetsu-to-Hagané, 51(1965), 19.

15) U.Lindeborg and K.Torssell: Trans. Met. Soc. AIME, 242(1968), 94.

16) H.Knüppel, K.Brotzmann and N.W.Förster: Stahl Eisen, 5(1965), 675.

17) N.F.Grevillius: Jernkont. Ann., 153(1969), 547.

18) S.Linder: Scand. J. Metall., 3(1974), 137.

19) K.Higashitani, K.Ogawa, G.Hosokawa and Y.Matsuno: J. Chem.Eng. Jpn., 15(1982), 299.

20) A.Nicholson and T.Gladman: Ironmaking Steelmaking, 13(1986), 53.

21) S.Taniguchi and A.Kikuchi: Tetsu-to-Hagané, 78(1992), 527.

22) H.Yin, H.Shibata, T.Emi and S.Suzuki: ISIJ Int., 37(1997), 936.

23) W.Lin and K.Shimme: Tetsu-to-Hagané, 84(1998), 7.

24) K.Morinaga, A.Oba and Y.Itoh: Tetsu-to-Hagané, 49(1963), 1663.

25) H.Hoff, H.Lessing and G.Masing: Stahl Eisen, 76(1956), 1442.

26) H.Kondo, T.Toh, R.Uemori, T.Suzuki, T.Chiba, H.Yamamura, M.Wakoh and E.Takeuchi: Tetsu-to-Hagané, 89(2003), 1000.

27) M.Sugiyama and G.Shigesato: J. Electron Microsc., 53(2004), 527.

28) SLAG ATLAS, 2nd ed., ed. by VDEh, Verlag Stahleisen, Düsseldorf, (1995), 504.

29) J.N.Israelachvili: Intermolecular and Surface Forces, 3rd ed., Academic Press, Waltham, (2011), 456.

30) J.Czarnecki and T.Dąbroś: J. Colloid Interface Sci., 78(1980), 25.

31) J.Gregory: Advances Colloid Interface Sci., 2(1969), 396.

32) J.Visser: Advances Colloid Interface Sci., 3(1972), 331.

33) L.Zhang, B.Rietow, B.G.Thomas and K.Eakin: ISIJ Int., 46(2006), 670.

34) K.Sasai and Y.Mizukami: CAMP-ISIJ, 14(2001), 76, CD-ROM.

35) SLAG ATLAS, 2nd ed., ed. by VDEh, Verlag Stahleisen, Düsseldorf, (1995), 32.

36) SLAG ATLAS, 2nd ed., ed. by VDEh, Verlag Stahleisen, Düsseldorf, (1995), 40. 